\title{
Introduced mammals, vegetation changes and seabird conservation on the Scott Islands, British Columbia, Canada
}

\author{
J. MARK HIPFNER, MOIRA J. F. LEMON and MICHAEL S. RODWAY
}

\begin{abstract}
Summary
The Scott Islands, British Columbia, Canada, support the largest aggregation of breeding seabirds in the eastern Pacific Ocean south of Alaska. However, large seabird populations were eradicated by American Mink Neovison vison and Raccoons Procyon lotor introduced to Lanz and Cox islands in the 1930s, while the ecological consequences of the introduction of European Rabbits Oryctolagus cuniculus to Triangle Island in the 1920 are unknown. We have seen dramatic changes in the vegetation on Triangle Island in recent decades, chiefly a decrease in Tufted Hairgrass Deschampsia cespitosa cover and a concomitant increase in Salmonberry Rubus spectabilis cover. We carried out vegetation surveys at Triangle Island (1989 and 2004) and its nearest neighbour, rabbit-free Sartine Island (1987 and 2006), to test the hypothesis that rabbits have caused these changes. We found, however, that similar changes have occurred at Sartine Island as at Triangle Island over the same time period. Because these two islands support the bulk of the world's breeding population of Cassin's Auklet Ptychoramphus aleuticus, a small seabird that selects grass-covered habitat but avoids tall Salmonberry for nesting, the vegetation changes raise serious concerns for a species that has experienced dramatic population declines in recent years. Restoration of seabird nesting habitat by removing American Mink and Raccoons from Lanz and Cox islands will be vital for long-term seabird conservation in the Scott Islands.
\end{abstract}

\section{Introduction}

Introduced mammals have dramatically altered ecological processes on many of the world's islands, including sites that support some of the largest assemblages of breeding seabirds (Howald et al. 2007, Donlan and Wilcox 2008, Jones et al. 2008). Their effects are many and varied. Predatory species kill adult birds and their offspring, ultimately eradicating ecologically important species and disrupting nutrient transfer from sea to land (Croll et al. 2005, Fukami et al. 2006). Herbivorous species can also have strong effects on island ecosystems, as when their browsing or grazing alters vegetation dynamics and accelerates rates of soil erosion, potentially causing landslides, and leading to the loss of seabird breeding habitat (Donlan et al. 2002, Frenot et al. 2005, van der Wal et al. 2008). In recent decades, programmes to eradicate introduced mammals from islands have become major components of global seabird conservation programmes (Taylor et al. 2000, Donlan et al. 2003).

Among important issues for seabird conservation on Canada's Pacific coast, problems with introduced mammals on breeding colonies stand out (Rodway 1991, Hartman et al. 1997). The Scott Islands, a small archipelago of five main islands plus associated rocks (Figure 1), support the largest aggregation of breeding seabirds in the north-eastern Pacific Ocean south of Alaska (Rodway 1991). However, three of the five islands support introduced mammals. Lighthouse keepers brought European Rabbits Oryctolagus cuniculus to Triangle Island in the 1920s, while 


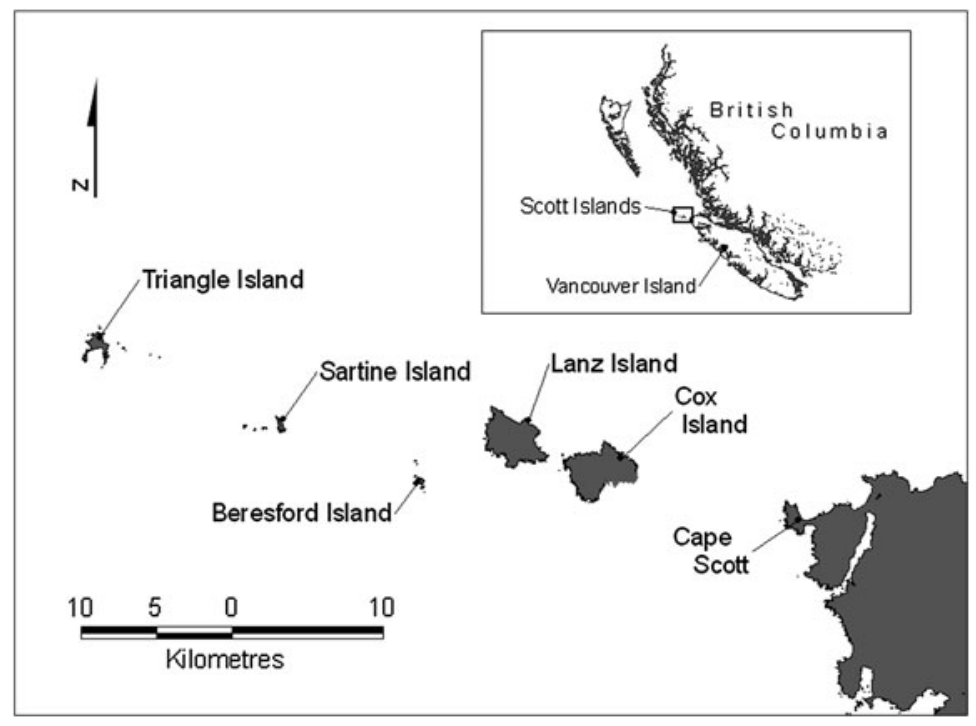

Figure 1. Map showing the location of the Scott Islands, British Columbia, Canada.

fur farmers brought American Mink Neovison vison to Lanz Island and Raccoons Procyon lotor to Cox Island in the 1930s (Carl et al. 1951). Subsequently, American Mink now occur on Cox Island, having colonised the island by dispersing from Lanz Island. The two carnivores virtually eradicated seabird populations on Lanz and Cox islands between 1949 and 1987 (Carl et al. 1951, Rodway et al. 1990) while there has been little assessment of the ecological effects of herbivorous rabbits on the plant and seabird communities at Triangle Island.

Introduced rabbits have altered plant communities on seabird islands around the world (Gillham 1963). On Triangle Island, we have noticed dramatic changes in the vegetation, chiefly a decrease in Tufted Hairgrass Deschampsia cespitosa cover and a concomitant increase in Salmonberry Rubus spectabilis cover. These trends are evident from descriptions of the island's vegetation over decadal scales (Carl et al. 1951, Rodway et al. 1990), and are obvious from photographs taken since the late 1980s of the steep sea slopes where most seabirds nest (Figure 2). Similar changes on seabird islands elsewhere have been causally linked to rabbit introductions, e.g., reductions in native Deschampsia at the Kerguelen Islands, in the southern Indian Ocean (Chapuis et al. 2004), and decreases in native tall tussock grasses at sub-Antarctic Macquarie Island (Scott and Kirkpatrick 2008). In both situations, at least partial recovery of the vegetation occurred after removal of rabbits (Chapuis et al. 2004) or reductions in their numbers due to disease (Scott and Kirkpatrick 2008).

Triangle Island supports the world's largest breeding population of Cassin's Auklet Ptychoramphus aleuticus, a small ( $\sim 18 \mathrm{og})$ zooplanktivorous seabird that at this colony selects areas covered in Tufted Hairgrass, while avoiding tall Salmonberry, for excavating its nesting burrows (Vermeer et al. 1979). In addition, we occasionally find dead Cassin's Auklets in amongst the branches of tall, dense Salmonberry, having become trapped either when landing on, or departing from, the nesting slopes. Therefore, we believe the vegetation changes have serious medium to long-term conservation implications for a species that is already in decline within the heart of its global range in the California Current marine system. The declines appear to be a consequence of recent oceanographic conditions (Bertram et al. 2005, Lee et al. 2007, Hipfner 2008).

Here, we test a simple hypothesis: that rabbits have been important factors driving the vegetation changes we have seen at Triangle Island. To do this, we carried out surveys on two islands, Triangle and Sartine, situated $\sim 10 \mathrm{~km}$ apart, over similar time periods. Like Triangle 

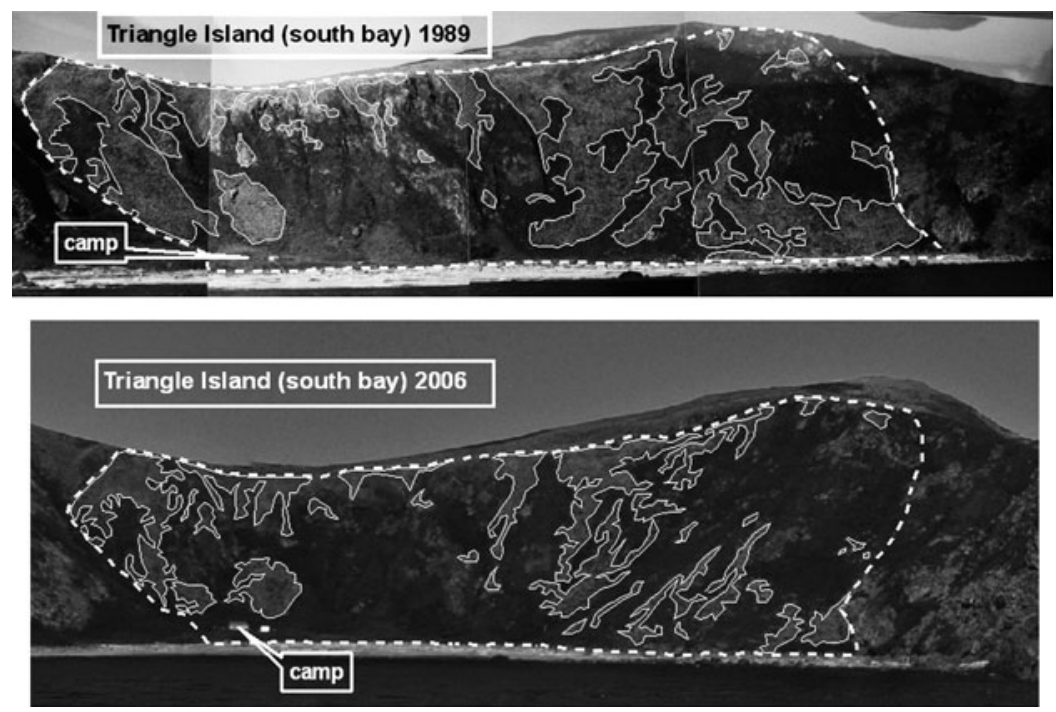

Figure 2. Comparative photos of the South Bay slope on Triangle Island in 1989 (top) and 2006 (bottom), showing the decrease in Tufted Hairgrass cover and increase in Salmonberry cover. Tufted Hairgrass areas are outlined in a solid white line on both photos, within a comparable area outlined in a dashed white line. Areas of Tufted Hairgrass were determined from examination of colour versions of the photographs.

Island, Sartine is a treeless island that supports a large breeding population of several hundred thousand Cassin's Auklets, but unlike Triangle, Sartine is free of rabbits or any other non-native mammals. Comparable (though not identical) baseline vegetation and seabird data were available from 1989 on Triangle Island and from 1987 on Sartine Island (Rodway et al. 1990). These earlier surveys, combined with surveys in 2004 (Triangle) and 2006 (Sartine), facilitated this comparison.

\section{Materials and methods}

The methods used to survey vegetation and seabird populations on the Scott Islands in the 1980s have been described in detail elsewhere (Rodway et al. 1990).

\section{Triangle Island}

As part of a long-term programme to estimate and track trends in seabird populations in British Columbia, fifteen $10 \mathrm{~m} \times 10 \mathrm{~m}$ permanent monitoring plots were established within the boundaries of the main part of the Cassin's Auklet breeding colony on Triangle Island in 1989. These plots were located along regularly-spaced transects which were part of a colony-wide census of the island conducted in that same year. The number of Cassin's Auklet burrows contained in each plot and the percentage and species composition of ground cover were recorded by teams of 3-4 people. Within each plot, the species or category type of vegetation (grass, herbs and forbs, Salmonberry) and its percentage ground cover were visually estimated, and distinct boundaries between vegetation types were drawn on a gridded map of the plot. To make the process easier, teams subdivided each plot into four $5 \mathrm{~m} \times 5 \mathrm{~m}$ sections, counted burrows and estimated ground cover in each section, then summed totals across the whole $100 \mathrm{~m}^{2}$ plot. 
The monitoring plots were first surveyed between 2 July and 16 August 1989, marked with metal stakes at each corner, and their locations drawn on a topographic map of the island. In later years, the plots were georeferenced with a Garmin GPS unit. The plot surveys were repeated from 11 June to July $4,2004$.

\section{Sartine Island}

On Sartine Island, vegetation cover and Cassin's Auklet burrow numbers were quantified in a total of $1871 \mathrm{~m} \times 1 \mathrm{~m}$ plots located at $5 \mathrm{~m}$ intervals along a system of seven regularly-spaced transects from 9 to 13 July 1987 . The starting point for each transect and its compass bearing were described and mapped on an outline of an aerial photo of the island. We resurveyed six of the seven transects on Sartine Island on 3-5 August 2006 (it was not safe to resurvey transect 6, given a rock slide in the interim). In addition, we visited Lanz and Cox islands on 5-21 July 1987 when most of the coastline of each island was explored on foot. Areas of the coastline on the two islands which were identified as potential seabird nesting habitat in 1987 were revisited on 9-12 August 2006.

\section{Results}

\section{Triangle Island}

At Triangle Island, our surveys of the set of $15100-\mathrm{m}^{2}$ monitoring plots in 1989 and 2004 revealed that the average area covered by grass decreased from $\sim 68$ to $\sim 38 \mathrm{~m}^{2}$ (paired- $t_{14}=5.87$, $P<$ 0.001), while the average area covered by Salmonberry increased from $\sim 13$ to $\sim 33 \mathrm{~m}^{2}$ (paired- $t_{14}=3.94, P=0.001$, Figure 3 ). The remaining changes were due to increases in ferns and various forbs on several plots. Over the same period, the average number of Cassin's Auklet burrows per plot decreased from 208 to 143 (paired- $t_{14}=4.38, P<$ o.001). Within individual plots, the change in the number of burrows was not correlated with changes in cover of either grass or Salmonberry (both $r^{2}<$ o.OI). However, the auklets' consistent use of grass-covered areas for burrowing was evident: a second order polynomial fit to the data pooled across the two time periods $\left(r^{2}=0.65, n=30, F=24.74, P<0.001\right.$; number of burrows per 100-m ${ }^{2}$ plot $=$ $115.1+0.03 \times$ grass cover $^{2}-1.14 \times$ grass cover) showed that the number of burrows per plot increased from $\sim 100$ in plots with no grass cover to $\sim 300$ in plots with $100 \%$ grass cover (Figure 4). There was also a weaker negative linear relationship between the number of burrows and Salmonberry cover $\left(r^{2}=0.19, n=30, F=5.83, P=0.02\right.$; number of burrows per $100 \mathrm{~m}^{2}$ plot $=204.20-1.23 \times$ Salmonberry cover $)$.

\section{Sartine Island}

Within the 187 (1987) or 175 (2006) $1-\mathrm{m}^{2}$ plots at Sartine Island, the median area under grass cover decreased from $0.95 \mathrm{~m}^{2}$ to $0.70 \mathrm{~m}^{2}$ (Mann-Whitney $U$-test, $\chi_{1}^{2}=21.6, P<0.001$ ) between 1987 and 2006 (Table 1 ). Salmonberry cover increased concurrently (Mann-Whitney $U$-test, $\chi_{1}^{2}=11.0, P<0.01$ ), although the median was o $\mathrm{m}^{2}$ in both 1987 and 2006 (Figure 5). Over the same time period, the mean number of Cassin's Auklet burrows on the $1 \mathrm{~m}^{2}$ plots decreased from 2.5 to $1.3\left(t_{360}=6.76, P<0.001\right)$. As at Triangle, the density of auklet burrows increased with grass cover at Sartine: a second order polynomial fit to the data pooled across the two time periods $\left(r^{2}=0.24, n=362, F=47.17, P<0.001\right.$; number of burrows per $1 \mathrm{~m}^{2}$ plot $=0.98+$ $0.0002 \times$ percentage grass cover ${ }^{2}+0.003 \times$ grass cover) showed that the number of burrows per plot increased from $\sim 1$ in plots with no grass cover to $\sim 3$ in plots with $100 \%$ grass cover (Figure 6 ). Again, there was also a weak negative linear relationship between the number of auklet burrows and the extent of Salmonberry cover $\left(r^{2}=0.14, n=362, F=56.74, P<0.001\right.$; number of burrows per $1-\mathrm{m}^{2}$ plot $=2.34-0.02 \times$ percent Salmonberry cover). 

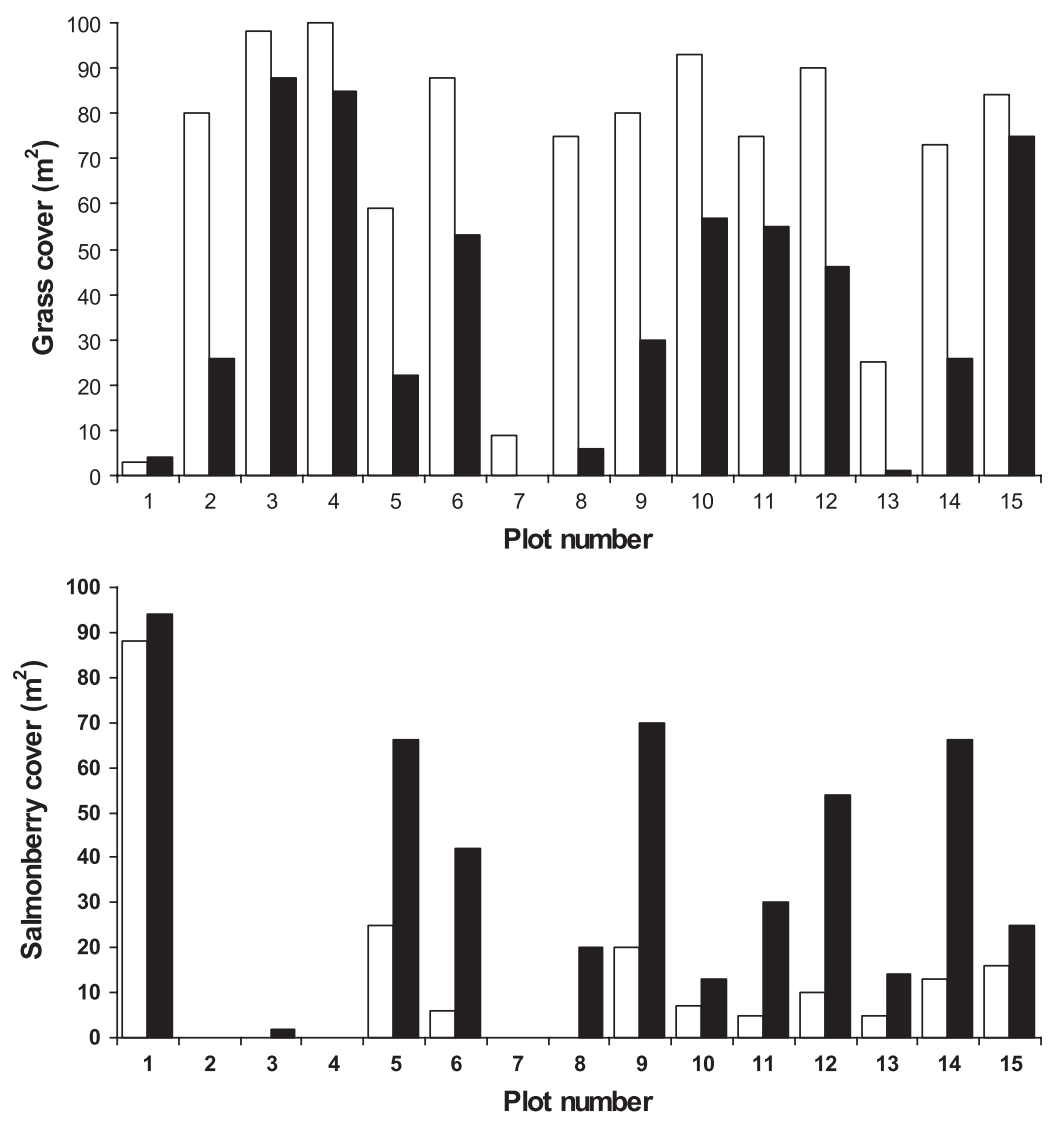

Figure 3. Area of grass (top) and Salmonberry (bottom) within fifteen $10 \mathrm{~m} \times 1$ om plots at Triangle Island in 1989 (white bars) and 2004 (black bars).

\section{Discussion}

At Triangle Island, our surveys revealed that there has been a dramatic decrease in Tufted Hairgrass cover and a concomitant increase in Salmonberry cover within the fifteen $100-\mathrm{m}^{2}$ monitoring plots between 1989 and 2004. Although differences in survey methods precluded a single analysis in which island could be included as a factor to enable direct island-to-island comparisons, the same general patterns were evident within the smaller $\left(1 \mathrm{~m}^{2}\right)$ and more numerous plots at Sartine Island between 1987 and 2006. The increase in Salmonberry appears to be occurring more slowly at Sartine than at Triangle, perhaps because Salmonberry has been well established for longer on the top of Triangle than on the top of Sartine (Carl et al. 1951). Regardless, the fact that the same types of changes in plant communities occurred both in the presence (Triangle) and the absence (Sartine) of rabbits suggests that rabbits have not been the primary agents of change, as they have on seabird islands elsewhere (Gillham 1963).

If not rabbits, then what is causing the vegetation changes? One possibility is that they are natural successional processes. Burrow-nesting seabirds such as Cassin's Auklet tend to reduce plant species diversity, and cause stunting or elimination of woody shrub cover (Bancroft et al. 2005, Ellis 2005). Stunting and elimination of woody vegetation and expansion of grassy habitat have been observed on other seabird colonies where burrowing areas have expanded (Rodway 


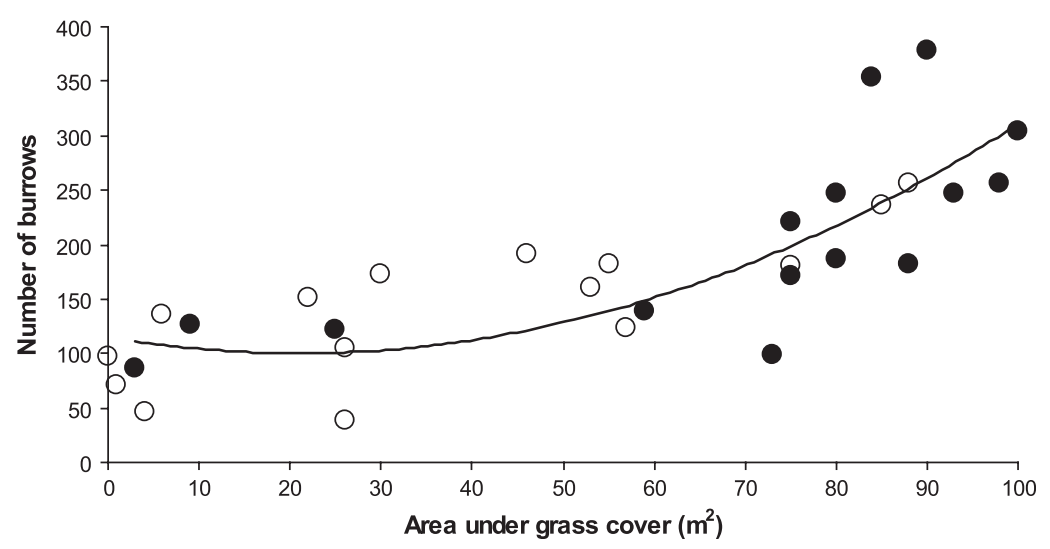

Figure 4. Relationship between the number of Cassin's Auklet burrows and area of grass cover on $100 \mathrm{~m}^{2}$ plots at Triangle Island in 1989 (filled circles) and 2004 (open circles).

et al. 2003). Thus, the possibility exists that recent vegetation changes witnessed on Triangle Island are a response to declining levels of activity and disturbance by burrow-nesting seabirds.

Climatic changes can also affect plant community dynamics on islands, and in some situations even override the more direct effects of invasive herbivores (Donlan et al. 2003). Over the period from 1970 to 2005 , summers in the Scott Islands have become warmer $\left(\sim 1^{\circ} \mathrm{C}\right.$ increase in the average air temperature from April to August inclusive) and drier ( $200 \mathrm{~mm}$ less total average precipitation), based on weather records at Cape Scott, $30 \mathrm{~km}$ east of Sartine Island (Figure 7). Many studies, most of them in high latitude and high altitude environments, have shown that climatic changes can alter the competitive interactions among species within plant communities (Dormann and Woodin 2002, Klanderud and Totland 2005). Climatic changes of similar magnitude to those occurring in coastal British Columbia have been linked to vegetation changes on seabird islands elsewhere, including decreases in native tall-tussock grasses (Donlan et al. 2003, Chapuis et al. 2004). Further research will be needed to determine the balance of factors, which

Table 1 . Vegetation cover (percentage of total area) within $1 \mathrm{~m}^{2}$ plots located at $5 \mathrm{~m}$ intervals along six transects on Sartine Island surveyed in both 1987 and 2006. Transect 6 was not surveyed in 2006 because it was unsafe to access.

\begin{tabular}{|c|c|c|c|c|c|c|}
\hline \multirow[t]{2}{*}{ Transect } & \multirow[t]{2}{*}{ Year } & \multirow[t]{2}{*}{ No. plots } & \multicolumn{2}{|c|}{$\%$ Grass } & \multicolumn{2}{|c|}{$\%$ Salmonberry } \\
\hline & & & Median & Range & Median & Range \\
\hline \multirow[t]{2}{*}{1} & 1987 & 27 & 100 & $70-100$ & $\mathrm{O}$ & $\mathrm{O}-2 \mathrm{O}$ \\
\hline & 2006 & 25 & 100 & $10-100$ & o & $0-6 o$ \\
\hline \multirow[t]{2}{*}{2} & 1987 & 17 & 80 & $80-95$ & o & $\mathrm{O}-\mathrm{O}$ \\
\hline & 2006 & 14 & 70 & $5-100$ & o & $\mathrm{O}-\mathrm{O}$ \\
\hline \multirow[t]{2}{*}{3} & 1987 & 48 & 100 & $0-100$ & o & $0-10$ \\
\hline & 2006 & 39 & 80 & $10-100$ & $\mathrm{O}$ & $0-60$ \\
\hline \multirow[t]{2}{*}{4} & 1987 & 53 & 50 & $0-100$ & 50 & $0-100$ \\
\hline & 2006 & 53 & 30 & 0-100 & 60 & $0-100$ \\
\hline \multirow[t]{2}{*}{5} & 1987 & 18 & 80 & $40-100$ & o & $\mathrm{O}-\mathrm{O}$ \\
\hline & 2006 & 18 & 40 & $0-100$ & o & $0-100$ \\
\hline \multirow[t]{2}{*}{7} & 1987 & 24 & 95 & $40-100$ & o & $\mathrm{O}-\mathrm{O}$ \\
\hline & 2006 & 26 & 85 & $10-100$ & o & $\mathrm{O}-\mathrm{O}$ \\
\hline
\end{tabular}




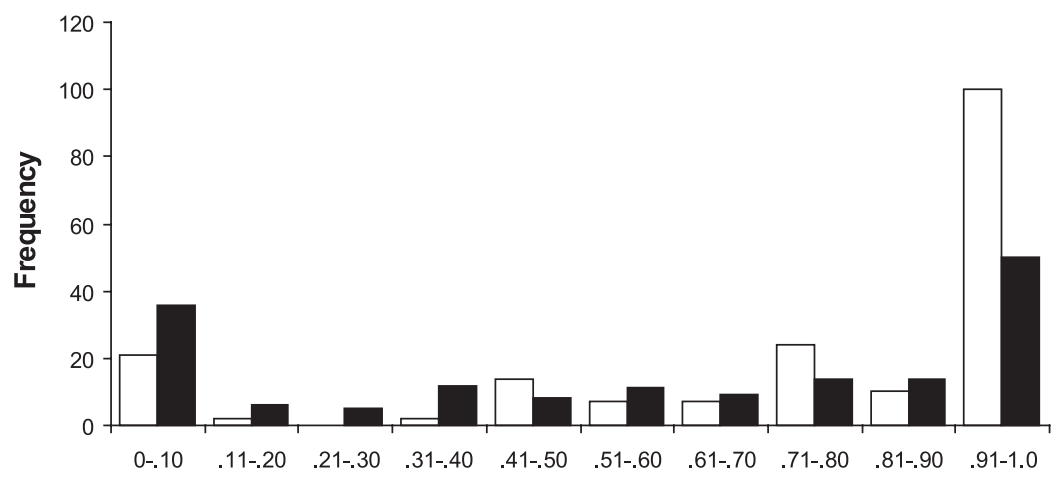

Area under grass cover $\left(\mathrm{m}^{2}\right)$

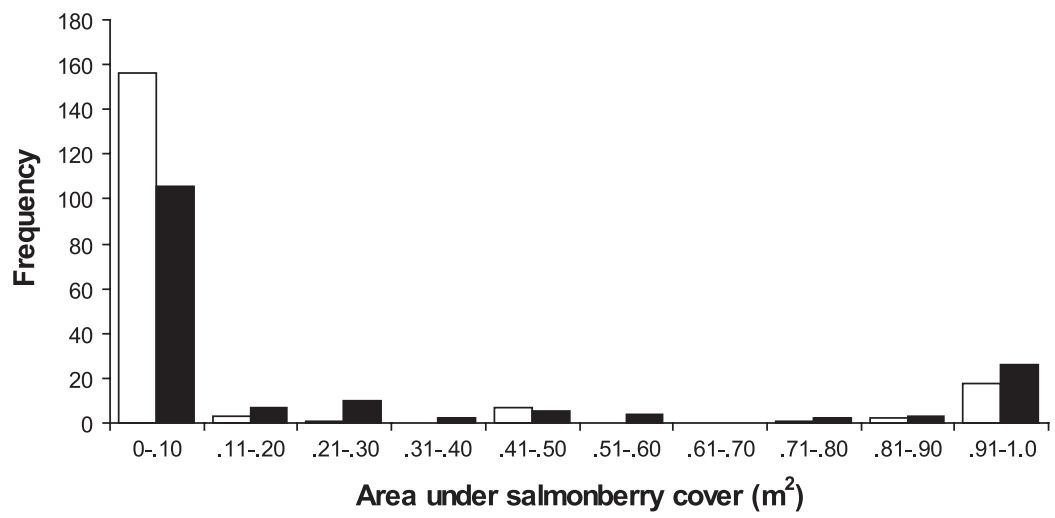

Figure 5. Frequency distribution showing the area covered by grass (top) and Salmonberry (bottom) within $1 \mathrm{~m} \times 1 \mathrm{~m}$ plots at Sartine Island in 1987 (white bars) and 2006 (black bars).

might act independently, interactively or synergistically, that are altering the competitive environment for plants in the Scott Islands.

Regardless of the causes of the changes in the plant community, we believe that they have serious medium to long-term conservation implications for the globally significant seabird populations on the Scott Islands. Of particular concern is that these islands support perhaps $70 \%$ of the world's breeding population of Cassin's Auklets (Rodway 1991) and that the population on Triangle Island has suffered dramatic declines, especially in the late 1990 (Bertram et al. 2005) and following the unusual atmospheric event in 2005 (Sydeman et al. 2006). The marked decrease in burrow density on Sartine Island suggests that the breeding population there has declined by a similar magnitude.

At Triangle Island, there was no correlation between temporal changes in burrow density and vegetation type, which indicates that changes in the plant community are not actively driving the birds' population declines. There is compelling evidence that the declines are related to recent oceanographic conditions (Mackas et al. 2007), which have decreased food availability and reduced the birds' productivity (Bertram et al. 2001, Hipfner 2008, Hipfner et al. in press) and survival (Bertram et al. 2005). We believe that the lack of correlation between changes in burrow density and vegetation reflects first, that the temporal changes in vegetation within plots were small compared to the variation among plots; and second, that the major factors driving declines in population size (thus burrow density) were oceanic rather than terrestrial. Nonetheless, the 


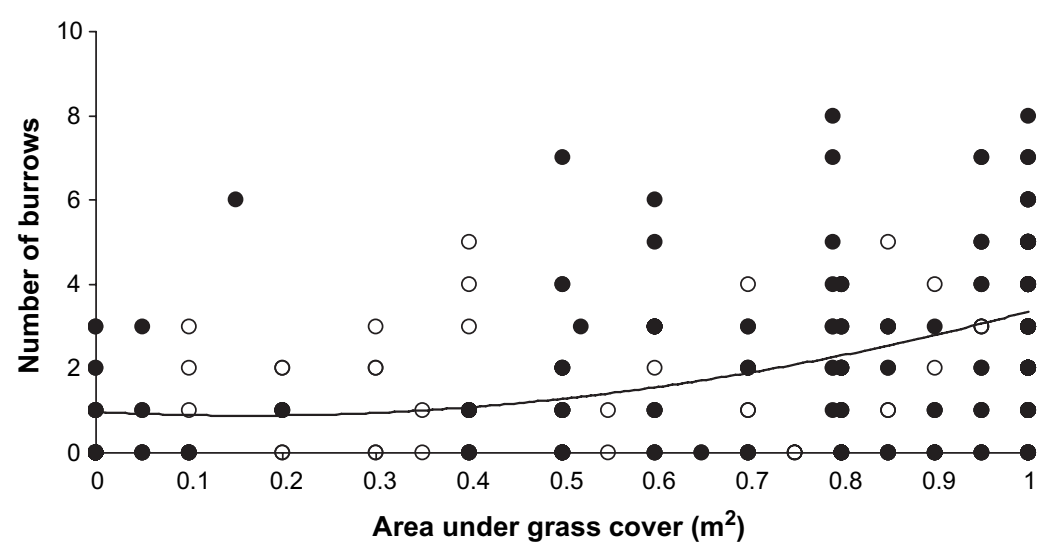

Figure 6. Relationship between the number of Cassin's Auklet burrows and area of grass cover on $1 \mathrm{~m} \times$ I m plots at Sartine Island in 1987 (filled circles) and 2006 (open circles). Note that many dots represent more than one data point.

decrease in tussock grass and increase in Salmonberry will certainly reduce the carrying capacity of the two outer Scott Islands for Cassin's Auklets: on both Triangle and Sartine islands, Cassin's Auklet nesting density increased threefold (from $\sim 1$ to $\sim 3$ burrows $\mathrm{m}^{-2}$ ) with grass cover, and decreased (weakly) with Salmonberry cover. Both tendencies were noted previously (Vermeer et al. 1979). But these authors showed that Cassin's Auklets particularly avoid tall Salmonberry, and this plant has invaded recently and remains relatively short $(<1 \mathrm{~m})$ in most of the areas where Cassin's Auklet plots were established on Triangle Island in 1989. We also encountered very little tall Salmonberry $(>1.5 \mathrm{~m})$ along the transects on Sartine Island.

Given that we can expect habitat modification to continue on the treeless outer islands (Triangle and Sartine), restoration of the larger, forested inner islands (Lanz and Cox) as seabird breeding sites through removal of American Mink and Raccoons should be viewed as a conservation priority. Cassin's Auklets readily nest on forested islands in Haida Gwaii (Rodway 1991). A faunal survey of Lanz and Cox islands in 1949 revealed that within two decades of their introduction, American Mink and Raccoons had decimated formerly large seabird breeding populations located on grass-covered headlands and fringing coastal areas (Carl et al. 1951). Among the species affected were Cassin's Auklet, Rhinoceros Auklet Cerorhinca monocerata, Black Oystercatcher Haematopus bachmani, Glaucous-winged Gull Larus glaucescens, and possibly Ancient Murrelet Synthliboramphus aleuticus, the latter a species of Special Concern in Canada.

Surveys in 1987 found that a small number of Cassin's Auklets continued to visit Lanz Island, with a few burrows found on grassy headlands, suggesting that the birds were still attempting to breed. However, the presence of scat containing feathers indicated that the seabirds were being killed by mink (Rodway et al. 1990). On our visit to Lanz and Cox islands in 2006 we found neither seabird burrows nor other evidence of breeding, and considerable amounts of featherfree American Mink and Raccoon scat. We did, however, find two feather piles in the forest on Lanz Island, one Cassin's Auklet and one Rhinoceros Auklet, which might indicate that birds are still visiting the colony. If so, then breeding populations could potentially re-establish themselves quickly following the removal of the introduced predators. Environment Canada's Canadian Wildlife Service, in collaboration with partners, is also assessing the marine ecosystem around the Scott Islands to develop the scientific support for policy or regulatory instruments, such as a Marine Wildlife Area, to assure long-term protection of seabirds and their foraging habitat. We believe that long-term conservation of these globally significant seabird populations will also require restoration of the terrestrial habitat that these populations depend on for breeding. 

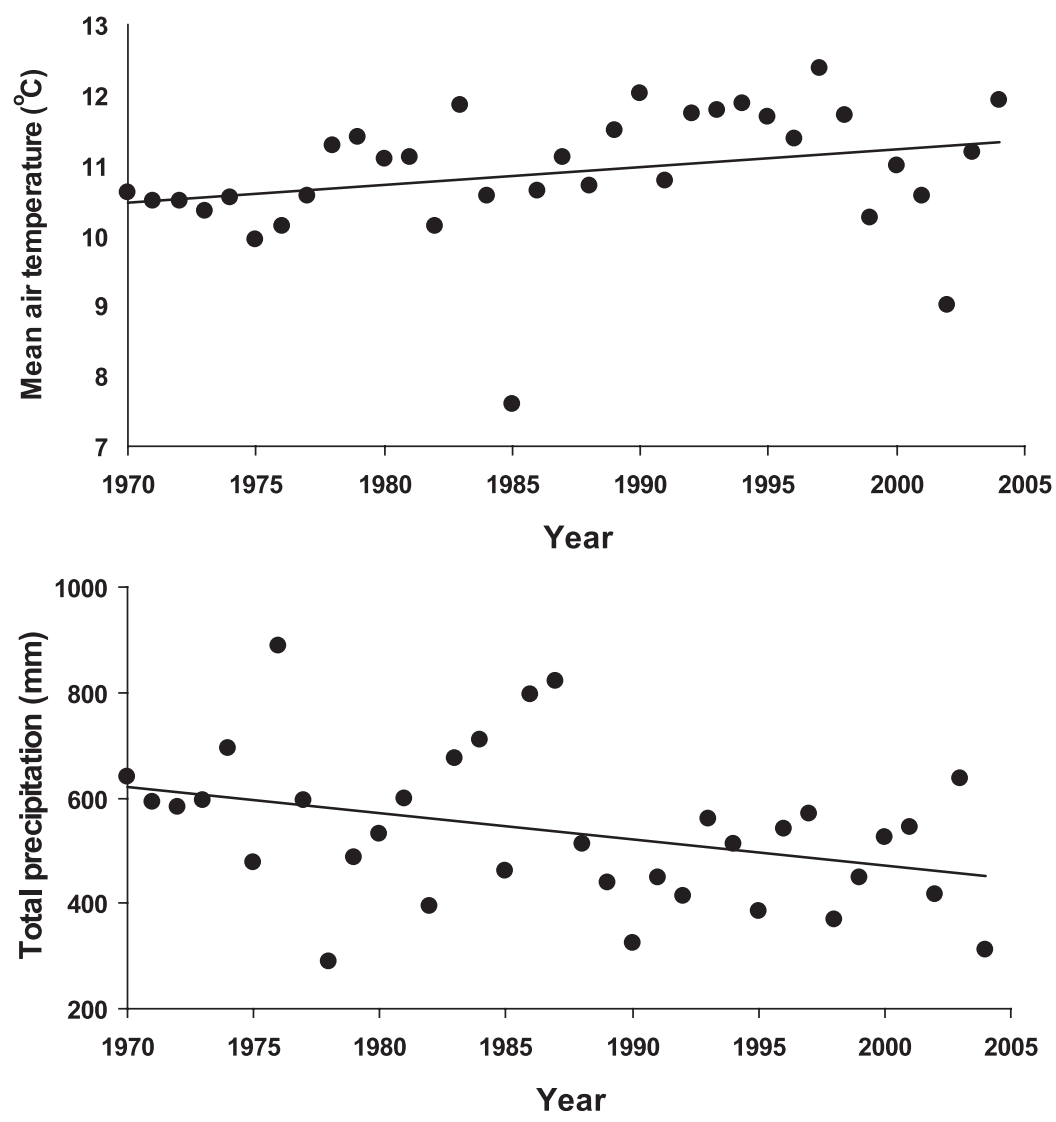

Figure 7. Annual mean air temperature (top), and annual total precipitation (bottom) from April to August inclusive, measured at Cape Scott light station, 1970-2004.

\section{Acknowledgements}

We thank Jessica Beaubier, Samantha Franks, Jennifer Greenwood, Glen Keddie, Nicole Koshure and Laurie Savard for assistance with surveys in 2004 and 2006. Funding was provided by Environment Canada's Canadian Wildlife Service and British Columbia Parks, while transportation to and from the islands was provided by West Coast Helicopters and Sea Legend Water Taxi. We dedicate this paper to Rudi Drent, who helped pioneer seabird research on the British Columbia coast.

\section{References}

Bancroft, W. J., Roberts, J. D. and Garkaklis, M. J. (2005) Burrowing seabirds drive decreased diversity and structural complexity, and increased productivity in insularvegetation communities. Austral. J. Bot. 53: 231-241.

Bertram, D. F., Harfenist, A. and Smith, B. D. (2005) Ocean climate and El Niňo impacts on survival of Cassin's Auklets from upwelling and downwelling domains of British Columbia. Can. J. Fish. Aquat. Sci. 62: 2841-2853.

Bertram, D. F., Mackas, D. L. and McKinnell, S. M. (2001) The seasonal cycle revisited: interannual variation and ecosystem consequences. Prog. Oceanogr. 49: 283-307. 
Carl, G. C., Guiget, C. J. and Hardy, G. A. (1951) Biology of the Scott Island group, British Columbia. Victoria: British Columbia Provincial Museum.

Chapuis, J. L., Frenot, Y. and Lebouvier, M. (2004) Recovery of native plant communities after eradication of rabbits from the subantarctic Kerguelen Islands, and influence of climate change. Biol. Conserv. 117: 167-179.

Croll, D. A., Maron, J. L., Estes, J. A., Danner, E. M. and Byrd, G. V. (2005) Introduced predators transform subarctic islands from grassland to tundra. Science 307: 19591961.

Donlan, C. J. and Wilcox, C. (2008) Diversity, invasive species and extinctions in insular ecosystems. J. Appl. Ecol. 45: 1114-1123.

Donlan, C. J., Croll, D. A. and Tershy, B. R. (2003) Islands, exotic herbivores, and invasive plants: Their roles in coastal California restoration. Restor.Ecol. 11: 524-530.

Donlan, C. J., Tershy, B. R. and Croll, D. A. (2002) Islands and introduced herbivores: conservation action as ecosystem experimentation. J. Appl. Ecol. 39: 235-246.

Dormann, C. F. and Woodin, S. J. (2002) Climate change in the Arctic: using plant functional types in a meta-analysis of field experiments. Funct. Ecol. 16: 4-17.

Ellis, J. C. (2005) Marine birds on land: a review of plant biomass, species richness, and community composition in seabird colonies. Vegetatio 181: 227-241.

Frenot, Y., Chown, S. L., Whinam, J., Selkirk, P. M., Convey, P., Skotnicki, M. and Bergstrom, D. M. (2005) Biological invasions in the Antarctic: extent, impacts and implications. Biol. Rev. 80: 45-72.

Fukami, T., Wardle, D. A., Bellingham, P. J., Mulder, C. P. H., Towns, D. R., Yeates, G. W., Bonner, K. I., Durrett, M. S., GrantHoffman, M. N. and Williamson, W. M. (2006) Above- and below-ground impacts of introduced predators in seabirddominated island ecosystems. Ecol. Lett. 9: 1299-1307.

Gillham, M. E. (1963) Some interactions of plants, rabbits and sea-birds on South African Islands. J. Ecol. 51: 275-294.

Hartman, L. H., Gaston, A. J. and Eastman, D. S. (1997) Raccoon predation on ancient murrelets on East Limestone Island, British Columbia. J. Wildl. Manage. 61: 377-388.

Hipfner, J. M. (2008) Matches and mismatches? Ocean climate, prey phenology and breeding success in a zooplanktivorous seabird. Mar. Ecol.-Progr. Ser. 368: 295-304.

Hipfner, J. M., McFarlane-Tranquilla, L. A. and Addison, B. (in press) Experimental evidence that both timing and parental quality affect breeding success in a zooplanktivorous seabird. Auk 127.

Howald, G., Donlan, C. J., Galvan, J. P., Russell, J. C., Parkes, J., Samaniego, A., Wang, Y. W., Veitch, D., Genovesi, P., Pascal, M., Saunders, A. and Tershy, B. (2007) Invasive rodent eradication on islands. Conserv. Biol. 21: 1258-1268.

Jones, H. P., Tershy, B. R., Zavaleta, E. S., Croll, D. A., Keitt, B. S., Finkelstein, M. E. and Howald, G. R. (2008) Severity of the effects of invasive rats on seabirds: A global review. Conserv. Biol. 22: 16-26.

Klanderud, K. and Totland, O. (2005) Simulated climate change altered dominance hierarchies and diversity of an alpine biodiversity hotspot. Ecology 86: 2047-2054.

Lee, D. E., Nur, N. and Sydeman, W. J. (2007) Climate and demography of the planktivorous Cassin's auklet Ptychoramphus aleuticus off northern California: implications for population change. J. Anim. Ecol. 76: 337-347.

Mackas, D. L., Batten, S. and Trudel, M. (2007) Effects on zooplankton of a warmer ocean: Recent evidence from the Northeast Pacific. Prog. Oceanog.y 75: 223-252.

Rodway, M. S. (1991) Status and conservation of breeding seabirds in British Columbia. Pp. 43-102 in J. P. Croxall, ed. Supplement to the status and conservation of the world's seabirds. Cambridge, UK: International Council for Bird Preservation.

Rodway, M. S., Lemon, M. J. F. and Summers, K. R. (1990) British Columbia seabird colony inventory: Scott Islands. Vancouver: Canadian Wildlife Service. (Technical Report Series No. 86).

Rodway, M. S., Regehr, H. M. and Chardine, J. W. (2003) Status of the largest colony of Atlantic Puffins in North America. Can. Field-Nat. 117: 70-75.

Scott, J. J. and Kirkpatrick, J. B. (2008) Rabbits, landslips and vegetation change 
on the coastal slopes of subantarctic Macquarie Island, 1980-2007: implications for management. Polar Biol. 31: 409-419.

Sydeman, W. J., Bradley, R. W., Warzybok, P., Abraham, C. L., Jahnke, J., Hyrenbach, K. D., Kously, V., Hipfner, J. M. and Ohman, M. D. (2006) Planktivorous auklet Ptychoramphus aleuticus responses to ocean climate, 2005: Unusual atmospheric blocking? Geophys. Res. Lett. 33: L22So9. doi: 10.029/2006GLo26376

Taylor, R. H., Kaiser, G. W. and Drever, M. C. (2000) Eradication of Norway rats for recovery of seabird habitat on Langara Island, British Columbia. Restor. Ecol. 8: 151-160.

Van Der Wal, R., Truscott, A. M., Pearce, I. S. K., Cole, L., Harris, M. P. and Wanless, S. (2008) Multiple anthropogenic changes cause biodiversity loss through plant invasion. Global Change Biol. 14: 14281436.

Vermeer, K., Vermeer, R. A., Summers, K. R. and Billings, R. R. (1979) Numbers and habitat selection of Cassin's Auklet breeding on Triangle Island, British Columbia. Auk 96: 143-151.

\section{J. MARK HIPFNER*, MOIRA J. F. LEMON}

Environment Canada, Pacific Wildlife Research Centre, RR\# 5421 Robertson Road, Delta, British Columbia, Canada, $V_{4} K_{3} \mathrm{~N}_{2}$.

\section{MICHAEL S. RODWAY}

Wildwing Environmental Research, Box 47, Gold Bridge, British Columbia, Canada, VoK 1 Po.

*Author for correspondence; e-mail: mark.hipfner@ec.gc.ca

Received 20 February 2009; revision accepted 29 April 2009; Published online 9 March 2010 